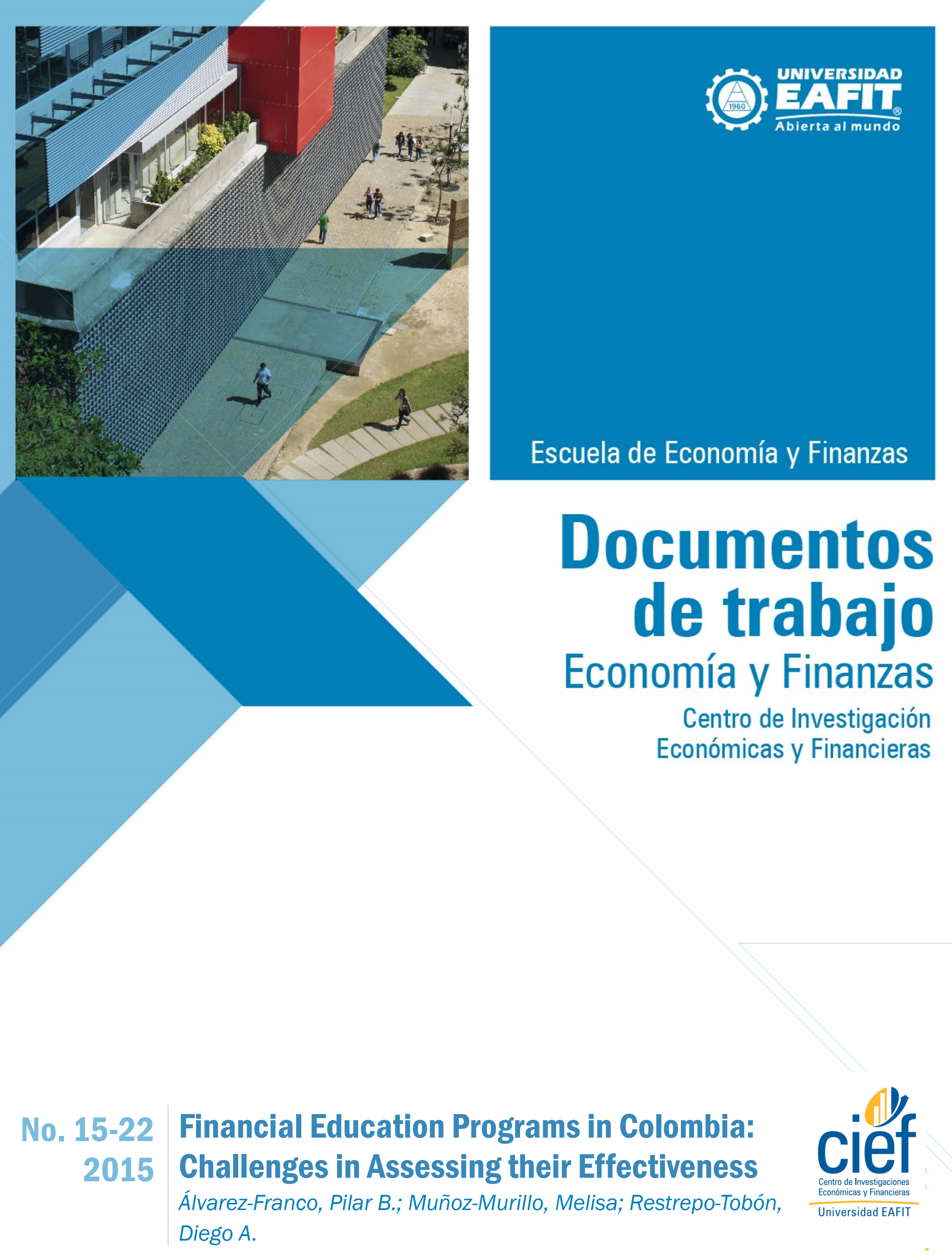




\title{
Financial Education Programs in Colombia: Challenges in Assessing their Effectiveness
}

\author{
Pilar B. Álvarez-Franco ${ }^{1}$ \\ Melisa Muñoz-Murillo \\ Diego A. Restrepo-Tobón ${ }^{3}$
}

\begin{abstract}
Financial education programs enjoy widespread governmental and financial industry support. They are considered an important tool for improving financial literacy, encouraging financial inclusion, and increasing consumer financial protection. Therefore, assessing their effectiveness is important to guarantee that public and private resources are allocated wisely. As we highlight in this paper, the available empirical literature casts serious doubts on the effectiveness of those programs in achieving their main objectives. Even properly designed - from an impact evaluation viewpoint - financial education programs fail to deliver long-run effects on individuals' financial literacy or financial choices. We highlight the challenges to evaluate the impact of financial education programs and, consequently, their merits. We showcase the international experience in assessing the effectiveness of these programs and draw lessons for Colombia. We offer a set of recommendations regarding the minimum set of attributes that financial education programs should have to allow serious policy evaluation.
\end{abstract}

\section{Keywords}

Financial literacy, financial education, impact evaluation.

JEL: A20, D04, D14, C180

\footnotetext{
${ }^{1}$ Assistant Professor of Finance, Universidad EAFIT, Medellín, Colombia. Email: palvare6@eafit.edu.co

${ }^{2}$ Universidad EAFIT, Medellín, Colombia. Email: amunozm@eafit.edu.co

${ }^{3}$ Assistant Professor of Finance, Universidad EAFIT, Medellín, Colombia. Email: drestr16@eafit.edu.co
} 


\section{Introduction}

Recent research shows that financial illiteracy is widespread worldwide (Lusardi \& Mitchell, 2011). In response, financial education and financial literacy programs figure prominently in the national public policy agenda of most countries (Xu \& Zia, 2012). In Colombia, financial education programs will affect the curricula of most primary and secondary schools. In addition, financial institutions are required by law to offer such programs to their current and potential consumers. Redy, Bruhn, \& Tan (2013) document that about $81 \%$ of Colombian citizens are unable to compute a simple interest rate, $72 \%$ do not save, $23 \%$ can determine how much they spent the week before, only $20 \%$ report been able to face unexpected expenses, and only $59 \%$ report they have enough to cover expenses after retirement. In 2012, Colombian students performed the worst in the financial literacy component of the PISA test.

Against this backdrop, financial education programs enjoy uncritical acceptance to the point that for politicians, policymakers, and journalists the terms financial education and financial literacy have become almost synonyms. In their discourse, these terms are associated, and often confounded, with desirable financial outcomes. National and local governments, financial institutions, and many nonprofit organizations embrace financial education programs as the panacea solution to increase financial literacy; and the latter, in turn, to improve consumer financial outcomes. However, the empirical evidence regarding the relation between financial education, financial literacy, and financial outcomes gives no clear indication of the effectiveness of financial education programs to increase financial literacy and to improve financial outcomes (Hastings, Madrian, \& Skimmyhorn, 2013).

Distinguishing between financial education, financial literacy, and financial outcomes is a prerequisite to establish the effects attributable to financial education programs in the presence of multiple confounding factors (e.g., preferences, cognitive abilities, numeracy, simultaneous intervention programs, etc., Fox, Bartholomae, \& Lee (2005)). Financial education refers to the process of providing individuals information, instruction or objective advice to improve their understanding of financial products, develop their skills to be aware of risk and opportunities, make informed choices and take effective actions for their financial wellbeing (OECD, 2005). Financial literacy refers to financial knowledge, financial ability, or both (Huston, 2010). On the other hand, financial outcomes refers to the skills, abilities, and behaviors regarding how people deal with financial matters (e.g. wealth accumulation, saving rates, acquiring an insurance, or managing a bank account, Hastings, Madrian, \& Skimmyhorn (2013)).

Considerable private and public resources are being dedicated to financial education programs. Therefore, identifying the precise effects of such policies is necessary to guarantee that public resources are allocated wisely. Most governments embracing financial education programs seem to believe that such programs are inescapably associated to better financial literacy and financial outcomes. Opportunistic politicians and the financial industry always welcomed such initiatives. Most public financial education programs and policies are, however, poorly designed and evaluating their effectiveness is a difficult task. ${ }^{4}$ To shed light on these issues, were view the empirical literature regarding the relationship between financial education, financial literacy, and

\footnotetext{
${ }^{4}$ Fox, Bartholomae, \& Lee (2005) document that several financial education initiatives developed in the United States since the 1990's failed to include an evaluation component in their design. Thus, most of these programs offered few insights regarding their eff ectiveness on improving financial literacy or financial outcomes.
} 
financial outcomes. We find that there are no clear cut results regarding these relations. The empirical evidence is inconclusive regarding the effects usually assumed to financial education programs on financial literacy and financial outcomes.

To highlight the challenges in assessing the evaluation of financial education programs, we showcase the Colombian experience. The Colombian case has several attractive features. First, by law, financial education is a right for Colombian consumers and financial institutions have the obligation to promote and deliver financial education programs as instructed by the Financial Superintendence of Colombia. ${ }^{5}$ In addition, Law 1450 of 2011 (Plan Nacional de Desarrollo 20102014), mandated the Ministry of National Education to define the set of basic financial and economic abilities that the Colombian curricula should include. Decree 457 of 2014 created a multiagency system to coordinate public and private financial education initiatives. Second, we show that most of the financial education programs implemented in Colombia fail to include an evaluation component. Two of the three programs that do include an impact evaluation component find, in the short run, a positive impact of financial education on financial literacy, but none on financial outcomes. Also, the Colombian government is implementing a national strategy for economic and financial education. Baseline and follow up surveys are still on development stage. Thus, our recommendations can shed light on how new programs should be designed in order to assess their effectiveness. ${ }^{6}$

The paper is organized as follows. Section 2 reviews the empirical literature regarding the relation between financial education, financial literacy, and financial outcomes. Section 3 reviews the literature concerning national financial education programs around the world. Section 4 highlights the main attributes that financial education programs should have to establish their effectiveness in improving financial literacy and financial outcomes. Section 5 evaluates the Colombian experience in assessing financial education programs. We conclude in Section 6.

\section{Literature Review}

Financial education programs aim at improving financial literacy and changing consumer financial behaviors. According to Hastings, Madrian, \& Skimmyhorn (2013), the empirical evidence in favor of a positive causal effect of financial education on either financial literacy or financial outcomes is limited and not as encouraging as one might expect. For instance, some empirical studies find almost no effects of financial education programs on financial outcomes (e.g., Jump\$tart Coalition for Personal Financial Literacy (2006), Mandell (2008)). In addition, Lusardi \& Mitchell (2014) demonstrate that financial education may have no effects on individuals with high impatience rates. The reason is that impatient consumers invest sub-optimally in the acquisition of financial knowledge. The same is true for individuals with low current and potential income. Hence, what are the main empirical facts regarding the effectiveness of financial education programs?

\footnotetext{
${ }^{5}$ See Law 1328 of 2009.

${ }^{6}$ According to Hastings, Madrian, \& Skimmyhorn (2013) well designed financial education programs should clearly state their main objectives. In particular, they should clarify if they aim to improve financial literacy or financial outcomes. When the goal is to improve financial outcomes other alternatives like strict regulation of the relation between financial consumers and financial institutions may be more eff ective. We do not address this literature in this study.
} 
As Lusardi \& Mitchell (2014) point out, few studies undertake either serious evaluations of the impact of financial education programs or careful cost-benefit analysis. Such studies are required to discern the merits of financial education programs and to make effective policy prescriptions. Lusardi \& Mitchell (2014), Lyons \& Neelakantan (2008), among many others, argue that evaluations of financial education programs should aim at establishing their effectiveness to modify financial outcomes and behaviors. Fox, Bartholomae, \& Lee (2005) highlight the challenges of conducting such evaluations and analyses.

Hastings, Madrian, \& Skimmyhorn (2013) offer a critical review of the effectiveness of financial education programs. They argue that most studies in the literature show a positive correlation between financial literacy and financial behaviors and outcomes. However, this association cannot be taken as evidence that financial education programs should be an effective mechanism to improve financial outcomes. In addition, mechanisms other than financial education may be more effective. For instance, policies that mitigate biases and decision making costs faced by financial consumers (Thaler \& Benartzi, 2004). Cole, Sampson, \& Zia (2011) examine the efficacy of offering monetary incentives for the use of bank accounts against financial education. They find that incentives are 2.5 times more cost-effective than financial education. In a related field, Calderon, Cunha, \& De Giorgi (2013) and Karlan \& Valdivia (2011) find that their business training programs were highly cost-effective.

Hastings, Madrian, \& Skimmyhorn (2013)'s review underscore that the causality between financial education and financial outcomes is difficult to pin down. First, financial literacy necessarily mediate the hypothesized association between financial education and financial outcomes. But individuals cite personal experience as the main factor in determining their financial learning, giving close to no role to financial education (Hilgert \& Hogarth, 2003). So, reverse causality is a major concern in assessing the relation between financial literacy and financial outcomes. ${ }^{7}$ Second, self-selection into financial education programs makes it difficult to identify the real effects, if any, of these programs on financial literacy or financial outcomes. Individuals engaging in financial education programs may possess unobserved characteristics that correlate with financial literacy and financial outcomes (Meier \& Sprenger, 2007). For instance, Hung \& Yoong (2013) find that individuals engaging in retirement financial advice programs are wealthier and have higher levels of financial literacy-measured and self-reported. Third, unobserved factors can make some individuals more likely to engage in financial education programs and, simultaneously, lead to better financial outcomes. For instance, as documented in Hastings, Madrian, \& Skimmyhorn (2013), the empirical literature shows a relationship between cognitive abilities and financial outcomes. This problem may lead to self-selection problems if individuals with higher cognitive abilities are more likely to participate in such programs or if financial outcomes strongly correlate with cognitive ability, as has been demonstrated in the literature (Banks \& Oldfield (2007), Gerardi, Goette, \& Meier (2010), Christelis, Jappelli, \& Padula (2010), Grinblatt, Keloharju, \& Linnainmaa (2009)). Fourth, omitted variable problems can bias empirical results. Research on the determinants of financial literacy find that impatience (Meier \& Sprenger, 2013), cognitive ability (Cole, Sampson, \& Zia (2011); Lusardi, Mitchell, \& Curto (2010)), peer characteristics (Lusardi, Mitchell, \& Curto, 2010), and risk aversion (Van Rooij, Lusardi, \&

\footnotetext{
${ }^{7}$ The endogeneity in financial literacy and financial outcome studies could arise from an error of measurement in the independent variable, a simultaneity between the independent and the dependent variable, or an omitted variable correlated with the independent variable (Hill, Griffiths, \& Lim, 2008).
} 
Alessie, 2011) are strongly related to financial literacy. Thus, without proper account for these hard to measure variables, the estimated effects of financial literacy on financial outcomes may be unreliable.

Other studies have investigated the relation between financial education and financial outcomes. Bernheim, Garrett, \& Maki (2001) exploit the change in financial education mandates in the United States as an exogenous variation of financial education to evaluate the long-term effects of financial education on self-reported rate of savings and wealth accumulation. They find a significant effect of financial education on both. However, Cole \& Shastry (2010), using the same natural experiment to determine whether there is a causal relation between financial education and saving decisions, find that financial education has no effect on financial outcomes; while cognitive ability significantly improves saving outcomes. Thus, the link between financial education and financial outcomes is still unclear. ${ }^{8}$

Likewise, there exists no consensus either on the relation between financial literacy and financial outcomes. Lusardi \& Mitchell (2005) and Hung, Meijer, Mihaly, \& Yoong (2009) examine the link between financial literacy and retirement planning for the United States. They find a high positive correlation between them. In contrast, Hung, Meijer, Mihaly, \& Yoong (2009) examine the relation between financial literacy and other financial outcomes (e.g., retirement savings and retirement portfolios management) and find no association between them. Cole, Sampson, \& Zia (2011) use two large household surveys for India and Indonesia. They find that financial literacy is positively correlated with having a bank account, even after controlling for per capita expenditure levels, household discount rates, and risk aversion. Nonetheless, in this study, expenditure levels, and not financial literacy, is a strong predictor of bank's accounts use.

The lack of sharp evidence regarding the relation between financial literacy and financial outcomes may be due to the above-mentioned endogeneity problems. To address this issue researchers resort to estimating methods based on instrumental variables. For instance, Van Rooij, Lusardi, \& Alessie (2011) use the financial situation of relatives to instrument financial literacy for individuals. They find that financial literacy positively impacts wealth accumulation and stock market participation. Lusardi \& Mitchell (2009) use high school financial education mandates in the United States as instrument for financial literacy. They find that advanced financial literacy levels positively impact retirement planning. However, Hung, Meijer, Mihaly, \& Yoong (2009) using the same strategy, but different methodology to measure financial literacy, find that the instrument used by Lusardi \& Mitchell (2009) is only weakly related to financial literacy.

Another solution to the problems of estimating the relation between financial education, financial literacy, and financial outcomes is to use control experiments. Two related experimental studies about business literacy training for female entrepreneurs come from Karlan \& Valdivia (2011) and Calderon, Cunha, \& De Giorgi (2013). Karlan \& Valdivia (2011) randomly assign the clients of a microfinance institution to treatment and control groups. The training consisted of 22 weekly sessions; additionally, a baseline survey before the intervention and follow-ups one and two years later were conducted. The authors find an effect of the training on business knowledge and practices (e.g. reinvestment of profits, innovations and increments on sales and revenues). Calderon,

\footnotetext{
${ }^{8}$ There could be other causes of financial literacy. Lusardi \& Mitchell (2009) find that studying economics in high school is associated to higher levels of financial literacy. Christiansen, Joensen, \& Rangvid (2008) find that studying economics in college is causally related to holding stocks.
} 
Cunha, \& De Giorgi (2013) in a similar work for rural Mexico find a positive impact of the program on participants' profits.

Bernheim \& Garrett (2003) use national surveys as an evaluation tool. They examine the effects of different financial education programs offered in the workplace and find that such programs increase savings for workers with low and moderate saving rates. While the effects are statistically insignificant for workers with high saving rates. For total wealth, the evidence is inconclusive. The authors' explanation for this results is that most employers offer these seminars and programs because employees have low disposition to save, and since the survey has no details of each program, the authors cannot control for the reason why employers offer them. This preexisting difference between participants and nonparticipants may underestimate the effects. An important study for Latin America is presented in Bruhn, de Souza Leáo, Legovini, Marchetti, \& Zia (2014). They show the results of a comprehensive financial education program for 20.000 Brazilian high school students. The program includes teacher and parent training sessions, didactic and innovative materials, and relevant curriculum according to the population. The authors find that financial education in the school increases the probability of having a bank account. Because the follow-up survey was conducted immediately after the intervention, the results are indicative only of short-term effects.

\section{National Financial Education Programs}

Despite the lack of empirical evidence on the effectiveness of financial education programs on either financial literacy or financial outcomes, many countries around the world have undertaken significant strategies to promote financial education programs.

Developed and developing countries give great importance to financial literacy to increase financial inclusion and empower people to make better financial decisions (OECD, 2014). According to Fox, Bartholomae, \& Lee (2005), policymakers and other stakeholders usually consider that financial education programs improve financial literacy. Under such a premise, The United States launched around ninety financial education programs in the last two decades. The developing world has followed through. For instance, the Brazilian government recently launched a national financial education program for high school students officially set in the national strategy for financial education of 2010 (Garcia, Grifoni, López, \& Mejía, 2013). ${ }^{9}$ To date fifty-five countries are designing, implementing or revising a national financial education strategy. ${ }^{10}$ More than one third of these countries indicated that surveys are the main evaluation tool to assess the effectiveness of their national financial education strategies, (OECD, 2014). At the moment, most surveys have not been conducted because national strategies are in an early stage (Grifoni \& Messy, 2012).

\footnotetext{
${ }^{9}$ A national strategy for financial education is defined by the OECD as "a nationally coordinated approach to financial education that consists of an adapted framework or program".

${ }^{10}$ The countries designing a national strategy are: Argentina, Canada, Chile, China, Colombia, Costa Rica, Croatia, El Salvador, France, Guatemala, Kenya, Lebanon, Malawi, Mexico, Pakistan, Peru, Poland, Romania, Saudi Arabia, Serbia, Sweden, Tanzania, Thailand, Uganda, Uruguay, and Zambia. The countries implementing one: Armenia, Brazil, Czech Republic, Denmark, Estonia, Ghana, India, Indonesia, Ireland, Israel, Korea, Latvia, Malaysia, Morocco Nigeria, Portugal, Russian Federation, Slovenia, and Turkey. The countries revising it: Australia, Japan, Netherlands, New Zealand, Singapore, Spain, South Africa, United Kingdom, and United States.
} 
In Colombia, Law 1450 of 2011 (Plan Nacional de Desarrollo 2010-2014), mandated the Ministry of National Education to define the set of basic financial and economic abilities that the Colombian school curricula should include. This mandate is being implemented by Decree 457 of 2014. Through this, the government created a multiagency system to coordinate public and private financial education initiatives within the framework of a national strategy for economic and financial education. Among other tasks, this agency should monitor and carry out impact evaluation of the programs developed within the national strategy. To date, the impact evaluation component is still under development.

In addition, since the Financial Reform of 2009 (Law 1328) ${ }^{11}$ financial institutions and financial industry associations have to provide financial education programs to their consumers regarding the products and services they offer. Different institutions have launched financial education programs in the last five years. According to the Inventory Survey on Financial Education Programs/Initiatives in Colombia (Encuesta de Mapeo sobre Programas/Iniciativas de Educación Económica y Financiera en Colombia) $)^{12}, 109$ institutions have or have initiated at least a financial education program. 31 (19\%) institutions were in the process of initiating at least one program. Out of the 103 institutions with a program already implemented, 65 (63\%) of them have developed the program within the previous five years. $53 \%$ of the institutions with a program develop it in-house, $29 \%$ through an alliance with a third party, and $18 \%$ have an alliance and develop part of the program directly. The most common stated objectives of these programs are 1) to improve personal financial management, 2) enhance financial knowledge and 3) develop general financial skills. Other objectives cited by these programs are to increase saving rates, improve financial products' use, manage risks, fraud prevention, and develop entrepreneurship skills. Each program may have more than one objective. The most frequently stated contents of these programs are saving and borrowing attitudes, financial products' use, budgeting, credit access, consumer rights and obligations, attitudes towards consumption, and numeracy basic skills. Banks, in particular, focus on financial products' use (See Table1), which may signal that such programs can be being used as financial propaganda rather than as objective financial education programs.

These financial education programs use mainly talks as part of the training plan. 85 programs rely on this mechanism. The rest of the programs, proceed as follow, 82 use educational materials, 71 training sessions, 67 electronic portals, 42 workshops, and 39 videos. Competitions, financial festivals, TV, radio, and press advertisements, and counseling are less frequent. Others programs include mailing, theater plays, radio programs, video-games, and applications for digital devices.

Without proper evaluation of these programs, however, it is difficult to establish if financial institutions are using them to either benefit consumers or themselves. This point is important to be considered by regulators since financial institutions' objectives may diverge from those in the public's interest. According to Hastings, Madrian, \& Skimmyhorn (2013), sometimes firms have incentives to help naïve consumers, but sometimes they obtain benefits from consumer illiteracy (e.g. consumers who pay higher fees are likely to be less literate, Choi, Laibson, \& Madrian (2010)). Besides, the evidence is small regarding firms investing in informative advertising to offset

\footnotetext{
${ }^{11}$ See Law 1328 of 2009, Title I, Chapter III, Literal f.

${ }^{12}$ Comisión Intersectorial de Educación Económica y Financiera (2014). The authors thank Nohora Forero Ramirez for her kindness at providing this document. Also specially thank to Nidia Garcia Bohórquez, Chief of Economics and Financial Education Section - Colombia Central Bank, for her willingness to help us in this research.
} 
consumer lack of financial knowledge (Hastings, Madrian, \& Skimmyhorn, 2013). In informative advertising models, firms seek to reduce frictions and information costs. In persuasive advertising models, by contrast, firms seek to convince consumers about special characteristics of a product, generate brand loyalty, and reduce price sensitivity. Hastings, Hortaçsu, \& Syverson (2013) in a study for the private Mexican pension system find that firms tend to compete by persuasive rather than informative advertising to make workers less price sensitive.

A particular important financial education program in Colombia is conducted by the selfregulatory agency of the Colombian capital market (Autorregulador del Mercado de ValoresAMV). The program Financial Education for All (Educación Financiera para Todos) is coordinated by the AMV on behalf of other financial institutions in order to avoid duplication and economize resources. 67 institutions among insurer companies, industry associations, banks, financial corporations, and brokerage firms participate in the program. ${ }^{13}$ The main focus of this program is to teach financial consumers about personal finance and other general financial topics. The standard delivery method are talks, online courses, competitions, and printed documents (AMV, 2015). Some of the media programs include Viva Seguro of Fasecolda which consists of 36 daily radio programs for low income station listeners (Rodríguez, Sanchez, \& Zamora, 2014) and the most recent, En tu Cuenta, Cada Peso Cuenta of Banca de las Oportunidades ${ }^{14}$ which started in February 2015 with a national tour that presented a monologue in 70 municipalities. The program also comprises a movie, a song, TV and radio advertisements, and radio dramas to be aired in national media (Banca de las Oportunidades, 2015).

Other programs worth mentioning are Colombia Lista of Citifoundation, Adelante con tu Futuro and Aulas Móviles. The first delivers tablets with a financial education application to participants of the Familias en Acción program (Citibank, 2014), a conditional cash transfer program for low-income rural households. Adelante con tu Futuro and Aulas Móviles use an alternative style to develop financial education workshops. They use a mobile classroom with capacity for 25 people. These programs reach several municipalities across Colombia (Banco de Bogotá (2013); BBVA (2014)). However, none of these programs evaluate their effectiveness.

Bancolombia, the largest Colombian commercial bank by assets, launched a program in 2009 call Educación Financiera. The program targeted students between fourth and eleventh grades. Bancolombia reports that half of the schools selected for the program deliver it to students. This program is the largest conducted in Colombia to date. It covers 2.346 teachers, 106.880 high school students, and 9.464 parents (Bancolombia, 2013). Likewise, the Bank BBVA Colombia launched in 2012 the program Escuela para el Emprendimiento, a financial education program for students between eighth and eleventh grades. This program targeted teachers and students training sessions on personal finance and entrepreneurship. This bank reports that by 2014, 40.000 high school students have participated in the program.

More recently, a pilot program for students known as Educación Económica y Financiera was developed by the Ministerio de Educación Nacional (MEN) and Asobancaria, a banking industry association. The implementation phase started in the second semester of 2014 (Asobancaria, 2014). The program is part of the National Strategy for Economic and Financial

\footnotetext{
${ }^{13}$ The complete list is in the Appendix.

${ }^{14}$ Banca de las Oportunidades is itself a program focused on improving financial access for low income households, and small and micro-entrepreneurs, managed by Bancóldex, and funded with public resources.
} 
Education set by government in the National Development Plan 2010-2014 (Departamento de Planeación Nacional, 2010).

Table1: Topics of Financial Education Programs in Colombia

\begin{tabular}{|c|c|c|c|c|c|c|c|c|c|c|c|}
\hline & \multicolumn{11}{|c|}{ Type of Institution } \\
\hline & $\begin{array}{c}\text { Mutual } \\
\text { Associations }\end{array}$ & Corporations & $\begin{array}{l}\text { Credit } \\
\text { Unions }\end{array}$ & $\begin{array}{l}\text { Financial } \\
\text { Institutions }\end{array}$ & $\begin{array}{l}\text { Education } \\
\text { Institutions }\end{array}$ & Federations & Multilaterals & NGOs & $\begin{array}{l}\text { Public } \\
\text { Sector }\end{array}$ & Other & Tota \\
\hline $\begin{array}{l}\text { Saving/ } \\
\text { borrowing } \\
\text { activities }\end{array}$ & 2 & 5 & 30 & 22 & 8 & 1 & 1 & 7 & 8 & 4 & 88 \\
\hline $\begin{array}{l}\text { Financial } \\
\text { products use }\end{array}$ & 2 & 6 & 20 & 30 & 10 & 1 & - & 2 & 5 & 7 & 83 \\
\hline Saving & 2 & 3 & 27 & 25 & 10 & 1 & - & 5 & 8 & 2 & 83 \\
\hline Budgeting & 1 & 2 & 20 & 22 & 9 & 2 & 1 & 6 & 5 & 4 & 72 \\
\hline Credits & 2 & 3 & 25 & 22 & 5 & 1 & - & 4 & 6 & 4 & 72 \\
\hline $\begin{array}{l}\text { Consumer } \\
\text { rights/ } \\
\text { obligations }\end{array}$ & 1 & 2 & 3 & 20 & & 2 & - & 2 & 6 & 5 & 41 \\
\hline $\begin{array}{l}\text { Attitudes } \\
\text { towards } \\
\text { consumption }\end{array}$ & - & 1 & 13 & 10 & 7 & - & - & 4 & 1 & 4 & 40 \\
\hline $\begin{array}{l}\text { Numeracy } \\
\text { basic skills }\end{array}$ & 1 & 1 & 2 & 5 & 8 & - & 1 & 3 & 4 & 3 & 28 \\
\hline Others & - & 2 & 2 & 10 & 3 & 2 & 2 & 1 & 5 & 1 & 28 \\
\hline Insurance & 1 & - & 7 & 7 & 2 & 1 & - & 1 & 3 & 2 & 24 \\
\hline Taxation & 1 & & 3 & 3 & 5 & 1 & - & - & 3 & 1 & 17 \\
\hline $\begin{array}{l}\text { Financial } \\
\text { fraud }\end{array}$ & & 1 & 2 & 8 & 2 & - & - & - & - & 2 & 15 \\
\hline Retirement & 1 & - & 6 & 7 & & - & - & - & - & - & 14 \\
\hline $\begin{array}{l}\text { Mobile } \\
\text { banking }\end{array}$ & - & 1 & 1 & 7 & 2 & - & - & - & - & 3 & 14 \\
\hline $\begin{array}{l}\text { Money } \\
\text { remittance/ } \\
\text { transfers }\end{array}$ & - & - & & 1 & 1 & - & - & - & - & - & 2 \\
\hline
\end{tabular}

Source: Adapted from the Encuesta de Mapeo sobre Programas/ Iniciativas de Educación Económica y Financiera en Colombia (2014)

\section{Impact Evaluation of Programs}

Many governments launch policies seeking to achieve different outcomes that improve people's wellbeing. However, the evaluation component of such policies commonly focuses on monitoring the delivery of the program rather than on evaluating the impact of these policies on the desired outcomes. Monitoring differs from evaluating since the former collects descriptive information about the operation and delivery of the programs, instead of assessing the performance of a policy 
(Yoong, Mihaly, Bauhoff, Rabinovich, \& Hung, 2013). Impact evaluation attempts to solve this deficiency by measuring the effects of a program on its outcomes. Financial education and financial literacy programs worldwide usually involve no impact evaluation components.

The importance of impact evaluation for financial education programs lies in its ability to improve policy design. There are two channels through which impact evaluation achieve its objective (Bernal \& Peña, 2011). First, it allows the allocation of limited resources for the most effective programs. Second, since it provides unbiased evidence of the program effectiveness, it reduces political opportunism and underinvestment. As Robinson \& Torvik (2005) find, some politicians have incentives to develop projects with negative social surplus, but with the ability of influencing voters' behavior. In Colombia, Camacho \& Conover (2011) find local political manipulation of a poverty index used by most social programs to select beneficiaries. They document the abnormal discontinuities at the eligibility threshold of the index right before election periods. The discontinuities started to occur in 1998, right after the politicians realized the algorithm used to figure out the poverty score. The manipulation of the index makes people to appear poorer than they really are and makes them eligible to participate in these programs.

The concern of impact evaluation is to measure the causal effects a program has on its outcomes. To establish causality due to the program one needs to measure the outcome variable of those individuals that participated in the program (e.g., the treated individuals) and compare it with the value that the outcome variable would have taken if the individuals had not participated in the program (which is obviously unobserved), (Yoong, Mihaly, Bauhoff, Rabinovich, \& Hung, 2013). Individuals not participating in the program are labeled untreated. Rosenbaum \& Rubin (1983) consider measurement of causal effects as a missing data problem because the value of the outcome variable for individuals that did not participate in the program is not observable. This is known as the counterfactual. Building this counterfactual convincingly is a critical step in any serious evaluation. Different methodologies are available to construct such a counterfactual (Blundell \& Dias, 2009). Evaluation methods which compare treated with untreated after the intervention or treated participants over time yield no reliable results (Duflo, Glennerster, \& Kremer, 2007). In the first design, the difference between participant and nonparticipant outcomes may be generated by the program or by the preexisting differences in their characteristics. So, we cannot attribute any effects to the program. This is called the selection bias problem. In addition, some variables that influence outcomes may change since the introduction of the program.

In the impact evaluation literature, reliable methods to remove selection bias can be classified between experiments and quasi-experiments methods (Yoong, Mihaly, Bauhoff, Rabinovich, \& Hung, 2013). Experiments entirely remove the selection bias since they randomly assign eligible individuals from the population to a treatment group, people who receive the program, and a control group, people who do not (Duflo, Glennerster, \& Kremer, 2007). Therefore, treatment and control individuals are similar in all dimensions but the program itself. This allows the evaluator to measure the unbiased causal effects by the difference in means of the outcomes between the treated and the control group. In the absence of randomness, the individuals differ and evaluators should avoid direct comparisons (Rubin, 1974). When randomization is not possible, quasi- experiments are an option. Quasi-experiments attempt to mimic randomness using econometric tools (Blundell \& Dias, 2009) like propensity score matching, instrumental variables, regression discontinuity design, and difference-in-difference (Yoong, Mihaly, Bauhoff, Rabinovich, \& Hung, 2013). 
To conduct an experimental study it is important to consider whether to randomize at the individual or the group level (Duflo, Glennerster, \& Kremer, 2007) or whether to conduct a baseline survey. Aside from the level of randomization, sometimes is useful to conduct different treatments simultaneously to assess their effectiveness or a combination of them. The standard experimental method is called randomized control trial and is based on treatment randomization. One variation arises when it is not possible to exclude anyone from taking the program for ethical or practical reasons (Yoong, Mihaly, Bauhoff, Rabinovich, \& Hung, 2013). Encouragement design is an alternative method which randomized incentives instead of treatments. In their seminal work, Rosenbaum \& Rubin (1983) argue that propensity score matching solve the selection bias by matching treatment and control individuals according to their likelihood of being treated. This likelihood is obtained using the different observable characteristics of individuals.

When there exist unobservable characteristics affecting the outcomes, the instrumental variables approach presents an alternative to overcome this problem (Angrist \& Krueger, 2001). This approach attempts to obtain the exogenous variation of the outcomes by using an instrument variable strongly related to the explanatory variable and related to the outcomes only through the explanatory variable. Sometimes the instrument is derived from natural experiment as in Lusardi \& Mitchell (2009) and Hung, Meijer, Mihaly, \& Yoong (2009). Regression discontinuity design occurs when access to a program depends on an observable variable. The difference-in-difference approach exploit a policy shift which induce a form of randomness in the treatment assignment and generates a treatment and a comparison group. It compares the difference in treatment group characteristics before and after the policy shift with the before and after for the comparison group (Blundell \& Dias, 2009).

To choose the proper evaluation method, Blundell \& Dias (2009) provide three relevant criteria: the target outcomes; the available data; and the assignment mechanism, known as the assignment rule. The authors conclude that the assignment rule is in the center of this choice since its consideration determines whether an experimental or a quasi-experimental method should be used according to the available data. Figure 1 illustrates the process of selecting an evaluation method. The first consideration an evaluator faces is to assess the implementation of an evaluation plan before the intervention. When the study is prospective, there exists a higher chance of treatment randomization and a randomization control trial is suitable. If there is no possibility to treatment randomization, encouragement design becomes the appropriate method. Prospective evaluations often conduct a baseline survey for treatment and control group as well (Gertler, Martinez, Premand, Rawlings, \& Vermeersch, 2011).

When it is a retrospective evaluation, researchers should determine if there is a criteria for the treatment assignment which yields a treatment and a control group, in this case, regression discontinuity design is useful. Because propensity score matching is based on observable variables, a large data is necessary. When data for treated and untreated individuals before and after the intervention is available difference-in-differences is suitable. Instrumental variables are useful when evaluators believe that there are unobservable variables (Blundell \& Dias, 2009).

The choice of a proper evaluation method is crucial. According to Fernandes, Lynch, \& Netemeyer (2014), the results depend on the choice of the evaluation method. They divide studies into correlational and causal (experiments and quasi-experiments) and find that correlational studies obtain larger effects than causal studies on financial outcomes. They attribute this disagreement to 
the variables omitted in correlational studies. In that sense, several authors have claimed the necessity of more experimental studies to measure the unbiased effects of programs (Hastings, Madrian, \& Skimmyhorn (2013); Lusardi \& Mitchell (2014); Meier \& Sprenger (2013)). On the other hand, Rubin (1974) argues that experimental data should be used when possible; however, when it is not, the use of quasi-experimental methods to measure causal effects is a reasonable alternative.

All in all, evaluating the impact of financial education programs instead of monitoring them is required to determine their effectiveness. Likewise, it helps to improve the design of more effective interventions, to allocate limited resources to the best programs, and to avoid political opportunism.

Figure 1: Decision Tree for Selecting Impact Evaluation Design

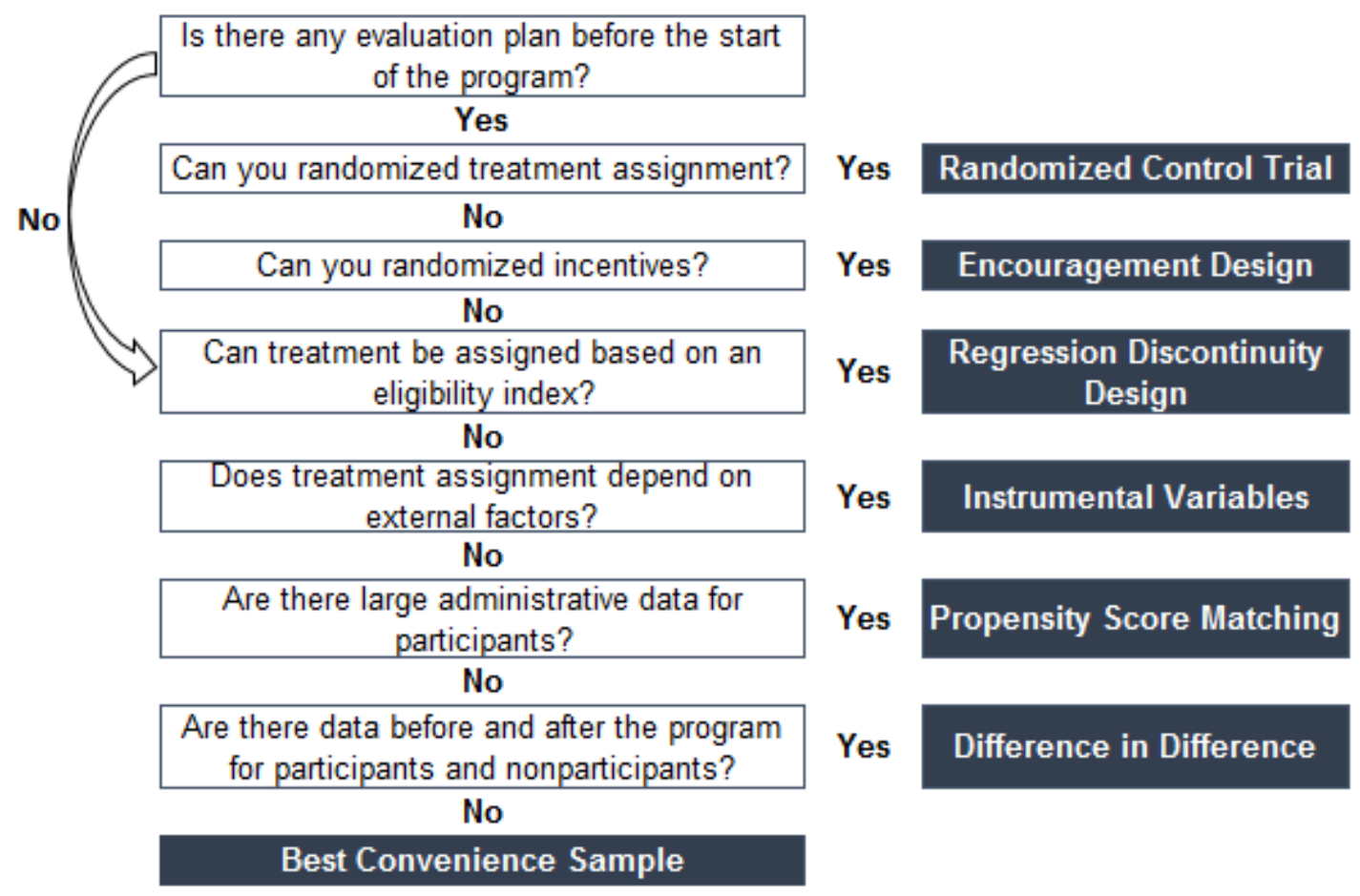

Source: Adapted from Yoong, Mihaly, Bauhoff, Rabinovich, \& Hung (2013)

\section{Evaluation of Financial Education Programs in Colombia}

According to the Encuesta de Mapeo sobre Programas/Iniciativas de Educación Económica y Financiera en Colombia, more than half of the programs identified by this survey fail to include an impact evaluation component. There are 109 institutions offering financial education programs. 76 (70\%) of them have not developed an impact evaluation assessment. The question asked in this 
survey, however, does not specify what impact evaluation means. ${ }^{15}$ Thus, it is difficult to assess if respondents answered with a rigorous understanding of what impact evaluation really implies. Our personal guess - based on the state of knowledge regarding impact evaluation in Colombia - is they did not. To our knowledge, only three financial education programs in Colombia have conducted an impact evaluation study: 1) Finance for change (Finanzas para el cambio), 2) Promoting a saving culture (Promoción de Cultura del Ahorro), and 3) Live safe (Viva Seguro). In addition, a new program Economic and Financial Education (Educación Económica y Financiera) is expected to conduct an impact evaluation analysis by the Colombian Central Bank in 2015 taking as a baseline the national survey SABER 9 2014 and the international survey PISA 2012 (Asobancaria, 2014).

The first impact evaluation comes from García (2012), who examines Finanzas para el Cambio, a small program on basic economics and personal finance. The program attempts to improve economic and financial knowledge, abilities, attitudes, skills, and behaviors of ninth- and tenth-grade students of low-income schools by training their math, economics, and social science teachers once each semester. 50 schools from Medellín, Cartagena, Bogotá, and Cali participated in the program. Schools' principals self-selected their schools into the program.

Given the lack of information about financial education levels by the time of the study, García (2012) conducted a 27 question survey in November 2010 for 1.518 students, 781 were considered treated and 737 assigned to the control group. The students belong to eight treated and eight non-treated schools. The questions included were adapted from Lusardi \& Mitchell (2005), the Jump\$tart Coalition financial literacy 2009 survey, the Financial Education Evaluation Manual developed by the National Endowment for Financial Education (NEFE) plus some questions specifically designed for the program. For budgetary and practical reasons, the author selected the sample using the best convenience sampling method, a nonrandom method when the criteria to choose the sample depends on the evaluator. Given the lack of randomness, this method generates a loss of external validity: the results cannot be generalized for all eligible population (Yoong, Mihaly, Bauhoff, Rabinovich, \& Hung, 2013). Thus, the 16 schools in the sample are not representative of the all 50 schools participating in the program. Regarding the internal validity, this answers the question of whether treatment and control individuals are similar (Yoong, Mihaly, Bauhoff, Rabinovich, \& Hung, 2013). Since this is a retrospective evaluation, treatment and control groups were not randomly built before the intervention. García (2012) builds an ex-post control group selecting schools that did not participated in the program. After that, however, she finds that treatments are more likely to work, receive any kind of free food in the school, pay no enrollment fees, and have less educated mothers.

These persistent differences between treated and control groups generate a selection bias, which the author attempts to remove using a quasi-experimental method: Propensity Score Matching. The idea is to construct a convincing counterfactual by matching individuals in the treated group to individuals in the control group based on the likelihood of participating in the program (Gertler, Martinez, Premand, Rawlings, \& Vermeersch, 2011). Because this likelihood is built using observable characteristics, how convincing the counterfactual is depends on whether the differences between treated and control groups lie only on observable variables (Angrist \& Krueger, 2001). García (2012) 's overall results support significant effects of the program on the economic and financial knowledge of the participants. However, she finds no evidence in favor of

${ }^{15}$ The question asked was "Is your institution conducting any type of evaluation to assess the impact of the program?". 
positive effects on abilities, attitudes, skills, and behaviors.

The second impact evaluation study comes from Núñez et al. (2012), who examine the program Promoción de Cultura del Ahorro, a small program launched by the Colombian government in 2009 to improve financial access. It has two components: financial education and monetary incentives. The educational component was developed during six workshops of two and half hours each. The topics include budgeting, savings, debt management, and insurance. Participants receive monetary incentives in the form of quarterly raffles among mothers with an active account at the rural state bank Banco Agrario. The prize was ten times the average balance account of the last quarter. The author randomize financial education and monetary incentives at the municipality level and conduct a baseline and a follow-up survey for 1.605 mothers in 2010 and in 2011, respectively. Three municipalities receive financial education, other three monetary incentives, three more receive both, and the last three, the control group, receive none. In the baseline, however, they find that treatments and controls differ. Two reasons explain the discrepancies. First, some municipalities started the program before the baseline survey. Second, the authors build clusters of municipalities according to population and poverty conditions, leading to a sample that does not represent all eligible municipalities.

To solve the endogeneity between the likelihood of participating and municipality poverty conditions, they use an Instrumental Variables methodology following a two-stage approach. In the first stage, they use a Stereotype Logistic Regression, a multinomial model which yields consistent measures of the likelihood of belonging to one of the treatment groups: financial education, monetary incentives, or both; according to municipality characteristics. They argue that this regression solves the endogenous variation generated by the preexisting differences between municipalities. The residuals from this regression capture the exogenous variation and can be used as a strong instrument. In the second stage, the authors use the residuals as the instrument to obtain the effects of participation on the outcomes by using a Difference-in-Difference methodology, which, in turn, solves the problems associated to the preexisting differences at the individual level found in the baseline survey. Of the 23 outcome variables they examine, they find increases in formal savings and saving capacities for all the treatment groups. However, they fail to find increases in access to formal financing and the use of financial products like debt and insurance. The authors also use a qualitative method and surveys for people from seven focal groups. From the qualitative results, Núñez et al. (2012) identify the main obstacles for household formal savings: the common use of purchase of animals and cash accumulation as a way of saving, and the lack of knowledge about financial products. On the other hand, informal mechanisms of financing like Christmas club accounts (natilleras in spanish) ${ }^{16}$ are preferred against formal financing because of the easiness of access to them as well as its low transaction costs. Additionally, bank requirements to qualify for a credit (e.g. assets ownership) are considered to be too high. Their overall results suggest an unbiased direction of the effect, its magnitude, however, is difficult to rationalize. Thus, the results are uninformative about what is more effective: incentives, financial education, or both.

In the first impact evaluation of a media program in Colombia, Rodríguez, Sanchez, \& Zamora (2014) examine Viva Seguro, a radio program on insurance which include 36 daily sessions for 225 low income station listeners. The content was didactic and relevant for the audience

\footnotetext{
${ }^{16}$ Informal funds created with resources of relatives, friends, and neighbors over the years and distributed at the end of the period.
} 
comprising radio dramas, expert, and public interviews. To avoid dropouts, they made daily raffles of $\$ 100.000$ and delivered a final jackpot of $\$ 3.000 .000$ Colombian pesos. The main concern regarding this evaluation is its internal validity. Two factors can affect it. First, although there is randomness at the radio station level (the authors randomly assigned six radio stations from Barranquilla, Bogota', and Pereira) and assign them to the treatment and control groups. However, the authors could not randomized at the individual level since listeners were loyal to their own radio station. Therefore, treatment and control individuals slightly differ in baseline: individuals in the treated group were more likely to be women. These differences persisted during the follow-up process given the high attrition rates: $80 \%$ in Barranquilla, $62 \%$ in Pereira, and $35 \%$ in Bogotá. Because of the high attrition rate in Barranquilla, the authors decided to remove this city from the analysis. The risk with attrition is that it contaminates the randomness set at the beginning of the intervention if people who drop out are different from people who do not. According to Yoong, Mihaly, Bauhoff, Rabinovich, \& Hung (2013) most high-quality impact evaluations of financial capability programs seek to have an attrition rate of $5 \%$ or less.

Self-selection is another problem since listening to the program is not random: people who decide to listen to the program may be different from people who do not. To deal with the differences between treated and control groups, the authors use a Difference-in-Differences method. This method overcomes the problem that treated and control groups do not have the same preintervention conditions. However, it does assume that they have the same trends over time (Gertler, Martinez, Premand, Rawlings, \& Vermeersch, 2011). The authors also use Instrumental Variables as a robustness test given the potential endogeneity between the decision to participate and the outcomes. The instrument they use was whether the individual reported he usually listen either to the treatment or to the control radio station. They also examine the effects of the radio program on six outcomes: number of risks and number of insurance products individual know, knowledge on basic insurance concepts, attitudes towards insurance, perceived capabilities and knowledge on insurance, and changes in behavior. Their results hold among the two methodologies. They find impacts on knowledge of number of risks and insurance products, and perceived capabilities and knowledge on insurance. However, they fail to find a significant impact on participants' knowledge of basic insurance concepts, attitudes towards insurance, and changes in behavior. Even though, two of the three programs planed an impact evaluation before the intervention, the main difficulty faced by the authors is to control for the lack of randomness of their samples either in the baseline or in the follow-up survey. This affects mainly the internal validity of the results. In addition, high attrition rates are also detrimental for internal validity. The lack of information about financial literacy levels before the start of the program presents difficult to overcome challenges to assess the real impact of the programs. Finally, budgetary constraints complicate the sampling and estimation process.

Overall, the available evidence for Colombia fails to support a causal effect of financial education programs on either financial knowledge or financial outcomes, and there is no evidence on long-term effects.

\section{Conclusion}

Significant public and private resources are being used in developing financial education programs 
around the world. Colombia is riding this wave as well. Their objectives are broad: to increase individuals' financial literacy, to improve individuals' financial outcomes, to increase financial consumer protection, and promote financial inclusion.

Recently enacted laws in Colombia mandate a general overhaul of primary and secondary education curricula to include the development of financial skills in the young. The law also mandates the financial industry to offer financial education programs to enhance financial literacy levels and improve financial consumer protection. How will the public know if such initiatives are worthwhile? We argue that without properly assessing the impact of such programs we take the risk of never knowing if they achieve their intended objectives. Thus, we may not know if the resources were wisely used.

In this paper, we show that the international empirical literature offers little evidence regarding the effectiveness of financial education programs in either improving financial literacy or changing individuals' financial outcomes. We analyze the Colombian experience regarding financial education and find that most programs lack a suitable impact evaluation component. Despite the large number of institutions-mostly financial institutions-carrying out financial education programs most of them do not evaluate the results of those programs. Out of more than one hundred financial education programs and initiatives currently being developed, we identify just three programs for which a rigorous impact evaluation assessment was carried out. These studies report short-term positive effects of the program on financial literacy levels but none on short- or long-term financial outcomes. Given the methodological challenges of these studies, the results should be taken with caution.

We also analyze the publicly available information regarding these programs. Judging by the way the programs are being delivered, their content, and overall design, some of them seem to be ill-conceived and their intended impact cannot be assessed. Colombian regulators should carefully consider how to evaluate the impact of the current wave of financial education programs.

Finally, we recommend setting quality standards for financial education programs offered by either the government or private institutions. A minimum set of requirements regarding the evaluation of the impact of such programs is a prerequisite to guarantee that public resources are wisely allocated and that financial education programs serve the public interest. Without such a requirement, publicly endorsed financial education programs may distort the current Colombian educational curricula or serve only as financial propaganda for financial institutions. 


\section{References}

Jump\$tart Coalition for Personal Financial Literacy. (2006). Financial literacy shows slight improvement among nation's high school students. Rep, Washington, DC.

AMV. (2015). Educación Financiera para Todos. Educación Financiera para Todos. Obtenido de http://www.amvcolombia.org.co/index.php?pag=home \\&id=110|197|0

Angrist, J. D., \& Krueger, A. B. (2001). Instrumental Variables and the Search for Identification: From Supply and Demand to Natural Experiments. Journal of Economic Perspectives, 15(4), 69-85.

Asobancaria. (2014). Informe de Sostenibilidad. Tech. rep.

Banca de las Oportunidades. (2015). En Tu Cuenta Cada Peso Cuenta. En Tu Cuenta Cada Peso Cuenta. Obtenido de http://www.cadapesocuenta.com

Banco de Bogotá. (2013). Informe de Gestión. Tech. rep.

Bancolombia. (2013). Programa de Educación Financiera del Grupo Bancolombia. Tech. rep.

Bancolombia, G. (2010). Educacion Financiera. Tech. rep., Bancolombia. Obtenido de http://www.grupobancolombia.com/contenidoCentralizado/corporativo/formatospdf /educacionFinanciera.pdf

Banks, J., \& Oldfield, Z. (2007). Understanding Pensions: Cognitive Function, Numerical Ability and Retirement Saving. Fiscal studies, 28(2), 143-170.

BBVA. (2014). Informe de Responsabilidad Corporativa. 106. Obtenido de https://www.bbva.com.co/documents/10180/2028799/Informe+Responsabilidad+C orporativa+2014.pdf/ff1fb80a-95d3-4c2d-8cca-887ea639fca2

Behrman, J. R., Mitchell, O. S., Soo, C., \& Bravo, D. (2010). Financial Literacy, Schooling, and Wealth Accumulation. National Bureau of Economic Research(Working paper No. 16452), 32.

Bernal, R., \& Peña, X. (2011). Guía Práctica para la Evaluación de Impacto.

Bernheim, B. D., \& Garrett, D. M. (2003). The effects of financial education in the workplace evidence from a survey of households. Journal of Public Economics, 87, 1487-1519.

Bernheim, B. D., Garrett, D. M., \& Maki, D. M. (2001). Education and Savings: The Long-Term Effects of High School Financial Curriculum Mandates. Journal of Public Economics, 80(3), 435-465.

Blundell, R., \& Dias, M. C. (2009). Alternative Approaches to Evaluation in Empirical Microeconomics. The Journal of Human Resources, 44(3), 565-640.

Blundell, R., Dearden, L., \& Sianesi, B. (2005). Evaluating the effect of education on earnings: models, methods and results from the National Child Development Survey. Journal of the Royal Statistical Society, 168(3), 473-512.

Bruhn, M., de Souza Leáo, L., Legovini, A., Marchetti, R., \& Zia, B. (2014). The Impact of High School Financial Education Experimental Evidence from Brazil. World Bank Policy Research Working Paper(Working paper No. 6723).

Calderon, G., Cunha, J. M., \& De Giorgi, G. (2013). Business Literacy and Development : Evidence from a Randomized Controlled Trial in Rural Mexico. National Bureau of Economic Research(Working paper No. 19740).

Camacho, A., \& Conover, E. (2011). Manipulation of Social Program Eligibility of Social Program Eligibility. American Economic Journal, 3(2), 41-65.

Choi, J. J., Laibson, D., \& Madrian, B. C. (2010). Why does the law of one price fail? An experiment on index mutual funds. Review of Financial Studies, 23(4), 1405-1432. 
Christelis, D., Jappelli, T., \& Padula, M. (2010). Cognitive abilities and portfolio choice. European Economic Review, 54(1), 18-38.

Christiansen, C., Joensen, J. S., \& Rangvid, J. (2008). Are economists more likely to hold stocks? Review of Finance, 12(3), 465-496.

Citibank. (2014). Informe de Sostenibilidad. Tech. rep.

Cole, S., \& Shastry, G. K. (2008). If You Are So Smart, Why Aren't You Rich ? The Effects of Education, Financial Literacy and Cognitive Ability on Financial Market Participation . unpublished, Harvard Business School.

Cole, S., \& Shastry, G. K. (2010). Is high school the right time to teach savings behavior? The effect of financial education and mathematics courses on savings. Harvad Business School/Wellesly College, 1-44.

Cole, S., Sampson, T., \& Zia, B. (2011). Prices or Knowledge? What Drives Demand for Financial Services in Emerging Markets . Journal of Finance, 66(6), 1933-1967.

Colombia, C. d. (2009). Ley 1328 de 2009. Ley 1328 de 2009(julio 15). Obtenido de https://www.superfinanciera.gov.co/SFCant/ConsumidorFinanciero/ley1328.pdf

Comisión Intersectorial de Educación Económica y Financiera. (2014). Encuesta de Mapeo sobre Programas / Iniciativas de Educación Económica y Financiera en Colombia. Tech. rep.

Departamento de Planeación Nacional. (2010). Plan Nacional de Desarrollo 2010-2014: Crecimiento Sostenible y Competitividad. Tech. rep. Obtenido de https://www.dnp.gov.co/Plan-Nacional-de-Desarrollo/PND-20102014/Paginas/Plan-Nacional-De-2010-2014.aspx

Duflo, E., Glennerster, R., \& Kremer, M. (2007). Using randomization in development economics research: a toolkit. Handbook of development economics, 4, 3895-3962.

Fernandes, D., Lynch, J. G., \& Netemeyer, R. G. (2014). Financial literacy, financial education, and downstream financial behaviors. Managment Science, 60(8), 1861-1883.

Financiera, S., Financieras, I., \& Cooperativas, E. (2010). Estrategia Nacional de Educación Económica y Financiera: Una propuesta para su implantación en Colombia. Tech. rep. Obtenido de https://www.superfinanciera.gov.co/SFCant/ConsumidorFinanciero/estratenaledufin anciera012011.pdf

Fox, J., Bartholomae, S., \& Lee, J. (2005). Building the case for financial education. Journal of Consumer Affairs, 39(1), 195-214.

Gabaix, X., \& Laibson, D. (2006). Shrouded Attributes, Consumer Myopia, and Information Suppression in Competitive Markets. The Quarterly Journal of Economics, 121(2), 505540. Obtenido de http://qje.oxfordjournals.org/content/121/2/505.abstract

García, N. (2012). El impacto de la educación económica y financiera en los jóvenes: el caso de Finanzas para el Cambio. Borradores de Economia, 687, 2-47.

Garcia, N., Grifoni, A., López, J. C., \& Mejía, D. (2013). La educación financiera en América Latina y el Caribe. Situación Actual y Perspectivas. Serie Políticas Públicas y Transformación Productiva, 12.

Gerardi, K., Goette, L., \& Meier, S. (2010). Financial literacy and subprime mortgage delinquency: Evidence from a survey matched to administrative data. Federal Reserve Bank of Atlanta Working Paper Series(2010-10).

Gertler, P. J., Martinez, S., Premand, P., Rawlings, L. B., \& Vermeersch, C. M. (2011). Impact evaluation in practice. Washinton D.C.: World Bank Publications. 
Grifoni, A., \& Messy, F.-A. (2012). Current Status of National Strategies for Financial Education. OECD Working Papers on Finance, Insurance and Private Pensions(16). Obtenido de http://www.oecd-ilibrary.org/content/workingpaper/5k9bcwct7xmnen $\$$ backslash\$nhttp://www.oecd-

ilibrary.org/docserver/download/5k9bcwct7xmn.pdf?expires=1378895971 \\&id=id \ \&accname=guest $\backslash$ \&checksum=68910FF7CC0D7950407835CE9025C673

Grinblatt, M., Keloharju, M., \& Linnainmaa, J. (2009). Do smart investors outperform dumb investors? Tech. rep., Chicago Booth School of Economics.

Hastings, J. S., \& Mitchell, O. S. (2011). How financial literacy and impatience shape retirement wealth and investment behaviors. National Bureau of Economic Research(Working paper No. 16740).

Hastings, J. S., Hortaçsu, A., \& Syverson, C. (2013). Advertising and competition in privatized social security: The case of Mexico. Tech. rep., National Bureau of Economic Research.

Hastings, J. S., Madrian, B. C., \& Skimmyhorn, W. L. (2013). Financial Literacy, Financial Education, and Economic Outcomes. Annual Review of Economics, 5(1), 347-373.

Heckman, J. J., \& Vytlacil, E. (2005). Structural Equations, Treatment Effects, and Econometric Policy Evaluation. Econometrica, 73(3), 669-738.

Heckman, J. J., Tobias, J. L., \& Vytlacil, E. J. (2001). Four Parameters of Interest in the Evaluation of Social Programs. Southern Economic Journal, 68(2), 210-223. Obtenido de http://search.ebscohost.com/login.aspx?direct=true $\backslash \& d b=b t h \backslash \& A N=5449543 \backslash \&$ site $=$ ehost-live

Hilgert, M. A., \& Hogarth, J. M. (2003). Household Financial Management: The Connection between Knowledge and Behavior. Federal Reserve Bulletin, 106(July), 309-322.

Hill, R. C., Griffiths, W. E., \& Lim, G. C. (2008). Principles of Econometrics (4th ed.). Wiley.

Hung, A., \& Yoong, J. (2013). The Market for Retirement Financial Advice. En O. S. Mitchell, \& K. Smetters (Edits.). New York, NY: Oxford University Press.

Hung, A., Meijer, E., Mihaly, K., \& Yoong, J. (2009). Building Up, Spending Down: Financial Literacy, Retirement Savings Management, and Decumulation. SSRN Journal(September). Obtenido de http://www.ssrn.com/abstract=1520203

Huston, S. J. (2010). Measuring Financial Literacy. Journal of Consumer Affairs, 44(2), 296-316.

Huston, S. J. (2012). Financial literacy and the cost of borrowing. International Journal of Consumer Studies, 36(5), 566-572. Obtenido de http://dx.doi.org/10.1111/j.14706431.2012.01122.x

Imbens, G. W., \& Wooldridge, J. M. (2009). Recent Developments in the Econometrics of Program Evaluation. Journal of Economic Literature, 47(1), 5-86.

Karlan, D., \& Valdivia, M. (2011). Teaching entrepreneurship: Impact of business training on microfinance clients and institutions. Review of Economics and Statistics, 93(2), 510527.

Lusardi, A., \& Mitchell, O. S. (2005). Financial Literacy and Planning: Implications for Retirement Wellbeing. Michigan Retirement Research Center(WP 108).

Lusardi, A., \& Mitchell, O. S. (2009). How Ordinary Consumers Make Complex Economic Decisions : Financial Literacy and Retirement Readiness How Ordinary Consumers Make Complex Economic Decisions : Financial Literacy and Retirement Readiness. National Bureau of Economic Research(Working paper No. 15350). Obtenido de http://pubs.aeaweb.org/doi/abs/10.1257/aer.98.2.413 
Lusardi, A., \& Mitchell, O. S. (2011). Financial literacy around the world: an overview. Journal of Pension Economics and Finance, 10(04), 497-508.

Lusardi, A., \& Mitchell, O. S. (2014). The Economic Importance of Financial Literacy : Theory and Evidence. Journal of Economic Literature, 52, 5-44.

Lusardi, A., Mitchell, O., \& Curto, V. (2010). Financial Literacy among the Young. Journal of Consumer Affairs, 44(2), 358-380.

Lyons, A. C., \& Neelakantan, U. (2008). Potential and Pitfalls of Applying Theory to the Practice of Financial Education. Journal of Consumer Affairs, 42(1), 106-112. Obtenido de http://dx.doi.org/10.1111/j.1745-6606.2007.00097.x

Mandell, L. (2008). Financial literacy of high school students. En J. Xiao (Ed.), Handbook of consumer finance research (págs. 163-183). New York, NY: Springer.

Marshall, M. N. (1996). Sampling for qualitative research Sample size. Family Practice, 13(6), 522-525.

Medina, C., \& Morales, L. (2007). Stratification and Public Utility Services in Colombia: Subsidies to Households or Distortion of Housing Prices? Borradores de EconomiaEconomía, 1-45.

Meier, S., \& Sprenger, C. (2007). Selection into financial literacy programs: Evidence from a field study. Tech. rep., Federal Reserve Bank of Boston.

Meier, S., \& Sprenger, C. D. (2013). Discounting financial literacy: Time preferences and participation in financial education programs. Journal of Economic Behavior and Organization, 95, 159-174. Obtenido de http://dx.doi.org/10.1016/j.jebo.2012.02.024

Meyer, B. D. (1995). Natural and Quasi-Experiments in Economics. Journal of Business \& Economic Statistics, 13(2), 151-161.

Núñez, J., Salazar, N., Castañeda, C., Rivas, G., Cuesta, L., \& Castillo, J. (2012). Primer Seguimiento de la Evaluación de Impacto del Piloto del Programa de Promoción de Cultura del Ahorro Resumen Ejecutivo. Tech. rep., Fedesarrollo. Obtenido de http://www.repository.fedesarrollo.org.co/handle/11445/185

OECD. (2005). Improving Financial Literacy: Analysis of Issues and Policies. Paris: OECD Publishing.

OECD. (2014). OECD / INFE progress report. Tech. rep., Paris. Obtenido de http://www.oecd.org/daf/fin/financial-education/OECD-INFE-Fin-Ed-G20-2014Progress-Report.pdf

Redy, R., Bruhn, M., \& Tan, C. (2013). Capacidades Financieras en Colombia: Resultados de la encuesta nacional sobre comportamientos, actitudes y conocimientos financieros. Tech. rep., Banco Mundial.

Robinson, J. A., \& Torvik, R. (2005). White elephants. Journal of Public Economics, 89(2-3), 197210.

Rodríguez, C., Sanchez, F., \& Zamora, S. (2014). On the Radio: Effectiveness of the Viva Seguro Financial Education Program. Serie Documentos Cede(2014-19). Obtenido de http://economia.uniandes.edu.co

Rosenbaum, P. R., \& Rubin, D. B. (1983). The Central Role of the Propensity Score in Observational Studies for Causal Effects. Biometrika, 70 SRC -(1083), 41-55.

Rubin, D. B. (1974). Estimating causal effects of treatments in randomized and nonrandomized studies. Journal of Educational Psychology, 66(5), 688-701. 
Schipani, A. (2014). Colombian banks spread their wings. Colombian banks spread their wings. Obtenido de http://www.ft.com/cms/s/0/9d8d4592-6bc5-11e3-a21600144feabdc0.html\\#axzz3f98zc0WK

Thaler, R. H., \& Benartzi, S. (2004). Save more tomorrow: Using behavioral economics to increase employee saving. Journal of political Economy, 112(S1), S164--S187.

Van Rooij, M. C., Lusardi, A., \& Alessie, R. J. (2012). Financial Literacy, Retirement Planning and Household Wealth. The Economic Journal, 122(2006), 449-478.

Van Rooij, M., Lusardi, A., \& Alessie, R. (2011). Financial literacy and stock market participation. Journal of Financial Economics, 101(2), 449-472. Obtenido de http://dx.doi.org/10.1016/j.jfineco.2011.03.006

Xu, L., \& Zia, B. (2012). Financial Literacy around the World: An Overview of the Evidence with Practical Suggestions for the Way Forward. Policy Research Working Paper(6107), 156.

Yoong, J., Mihaly, K., Bauhoff, S., Rabinovich, L., \& Hung, A. (2013). A Toolkit for the Evaluation of Financial Capability Programs in Low-, and Middle-Income Countries. Washington, DC: World Bank. Obtenido de https://openknowledge.worldbank.com/handle/10986/16294 
Appendix

\begin{tabular}{|c|c|c|}
\hline No. & Institución & Tipo de Institución \\
\hline 1 & AXA COLPATRIA SEGUROS S.A. & Aseguradora \\
\hline 2 & COMPAÑIIA DE SEGUROS BOLÍVAR S.A. & Aseguradora \\
\hline 3 & OLD MUTUAL SEGUROS DE VIDA S.A. & Aseguradora \\
\hline 4 & RIEGOS PROFESIONALES COLMENA S.A. & Aseguradora \\
\hline 5 & SEGUROS COMERCIALES BOLÍVAR S.A. & Aseguradora \\
\hline 6 & SEGUROS DE VIDA COLPATRIA S.A. & Aseguradora \\
\hline 7 & ASOBANCARIA & Asociación Gremial \\
\hline 8 & ASOBOLSA & Asociación Gremial \\
\hline 9 & ASOFIDUCIARIAS & Asociación Gremial \\
\hline 10 & ASOFONDOS & Asociación Gremial \\
\hline 11 & FEDELEASING & Asociación Gremial \\
\hline 12 & BANCO AGRARIO DE COLOMBIA S.A. & Banco \\
\hline 13 & BANCO BCSC S.A. & Banco \\
\hline 14 & BANCO COLPATRIA RED MULTIBANCA S.A. & Banco \\
\hline 15 & BANCOMPARTIR S.A. / FINANCIERA AMERICA S.A. & Banco \\
\hline 16 & BANCO DAVIVIENDA S.A. & Banco \\
\hline 17 & BANCO DE OCCIDENTE S.A. & Banco \\
\hline 18 & BANCO GNB SUDAMERIS S.A. & Banco \\
\hline 19 & BANCO CORPBANCA S.A. / HELM BANK & Banco \\
\hline 20 & BANCOLOMBIA S.A. & Banco \\
\hline 21 & CITIBANK - COLOMBIA S.A. & Banco \\
\hline 22 & CAPITALIZADORA BOLÍVAR S.A. & Capitalizadora \\
\hline 23 & CAPITALIZADORA COLMENA S.A. & Capitalizadora \\
\hline 24 & CAPITALIZADORA COLPATRIA S.A. & Capitalizadora \\
\hline 25 & CORPORACIÓN FINANCIERA COLOMBIANA S.A. & Corporación Financiera \\
\hline 26 & JP MORGAN CORPORACIÓN FINANCIERA S.A. & Corporación Financiera \\
\hline 27 & ACCIÓN FIDUCIARIA S.A. & Sociedad Fiduciaria \\
\hline 28 & BBVA FIDUCIARIA S.A. & Sociedad Fiduciaria \\
\hline 29 & CITITRUST S.A. & Sociedad Fiduciaria \\
\hline 30 & FIDUAGRARIA S.A. & Sociedad Fiduciaria \\
\hline 31 & FIDUCIARIA BOGOTÁ S.A. & Sociedad Fiduciaria \\
\hline 32 & FIDUCIARIA CENTRAL S.A. & Sociedad Fiduciaria \\
\hline 33 & FIDUCIARIA COLMENA S.A. & Sociedad Fiduciaria \\
\hline 34 & FIDUCIARIA CORFICOLOMBIANA S.A. & Sociedad Fiduciaria \\
\hline 35 & FIDUCIARIA DAVIVIENDA S.A. & Sociedad Fiduciaria \\
\hline 36 & FIDUCIARIA DE OCCIDENTE S.A. & Sociedad Fiduciaria \\
\hline 37 & FIDUCIARIA DEL PAÍS S.A. & Sociedad Fiduciaria \\
\hline 38 & FIDUCIARIA LA PREVISORA S.A. & Sociedad Fiduciaria \\
\hline 39 & FIDUCIARIA POPULAR S.A. & Sociedad Fiduciaria \\
\hline 40 & FIDUCIARIA OLD MUTUAL S.A. & Sociedad Fiduciaria \\
\hline 41 & FIDUCOLDEX S.A. & Sociedad Fiduciaria \\
\hline 42 & FIDUCOR S.A. & Sociedad Fiduciaria \\
\hline 43 & $\begin{array}{l}\text { CORPBANCA INVESTMENT TRUST/HELM FIDUCIARIA } \\
\text { S.A. }\end{array}$ & Sociedad Fiduciaria \\
\hline 44 & PROTECCIÓN S.A. & Fondo de Pensiones \\
\hline
\end{tabular}




\begin{tabular}{lcc}
45 & COLFONDOS S.A. & Fondo de Pensiones \\
46 & PORVENIR FONDO DE PENSIONES Y CESANTÍAS & Fondo de Pensiones \\
47 & OLD MUTUAL PENSIONES Y CESANTÍAS S.A. & Fondo de Pensiones \\
48 & SEGURIDAD COMPAÑ́A ADMINITRADORA DE FONDOS & Sociedad Administradora de \\
49 & DE INVERSION S.A. & Inversión \\
50 & ACCIONES Y VALORES S.A. & Sociedad Comisionista de Bolsa \\
51 & ALIANZA VALORES S.A. & Sociedad Comisionista de Bolsa \\
52 & ASESORES EN VALORES S.A. & Sociedad Comisionista de Bolsa \\
53 & ASESORÍAS E INVERSIONES S.A. & Sociedad Comisionista de Bolsa \\
54 & BBVA VALORES COLOMBIA S.A. & Sociedad Comisionista de Bolsa \\
55 & BTG PACTUAL S.A. COMISIONISTA DE BOLSA & Sociedad Comisionista de Bolsa \\
56 & CASA DE BOLSA S.A. & Sociedad Comisionista de Bolsa \\
57 & CITIVALORES S.A. & Sociedad Comisionista de Bolsa \\
58 & COMPAÑÍA PROFESIONALES DE BOLSA S.A. & Sociedad Comisionista de Bolsa \\
59 & CREDICORP CAPITAL S.A. & Sociedad Comisionista de Bolsa \\
60 & DAVIVIENDA CORREDORES S.A. & Sociedad Comisionista de Bolsa \\
61 & GLOBAL SECURITIES COLOMBIA S.A. & Sociedad Comisionista de Bolsa \\
62 & CORPBANCA COMISIONISTA DE BOLSA S.A & Sociedad Comisionista de Bolsa \\
63 & SERFINCO S.A. & Sociedad Comisionista de Bolsa \\
64 & SERVIVALORES GNB SUDAMERIS S.A. & Sociedad Comisionista de Bolsa \\
65 & OLD MUTUAL VALORES S.A. & Sociedad Comisionista de Bolsa \\
66 & ULTRABURSÁTILES S.A. & Sociedad Comisionista de Bolsa \\
67 & VALORES BANCOLOMBIA S.A. & Sociedad Comisionista de Bolsa \\
\hline
\end{tabular}


